\title{
Childhood Kidney Neoplasm
}

National Cancer Institute

\section{Source}

National Cancer Institute. Childhood Kidney Neoplasm. NCI Thesaurus. Code C6563.

A kidney neoplasm that occurs in children. 